\title{
HSPD1 wt Allele
}

National Cancer Institute

\section{Source}

National Cancer Institute. HSPD1 wt Allele. NCI Thesaurus. Code C104339.

Human HSPD1 wild-type allele is located in the vicinity of 2q33.1 and is approximately 30 $\mathrm{kb}$ in length. This allele, which encodes $60 \mathrm{kDa}$ heat shock protein, mitochondrial, is involved in both import and folding of mitochondrial proteins. Mutation of the gene is associated with spastic paraplegia 13 and leukodystrophy hypomyelinating type 4 . 